\title{
Climate change and agricultural productivity in Brazil: future perspectives
}

\author{
JULIANO ASSUNÇÃO \\ Department of Economics, Pontificia Universidade Católica do Rio de Janeiro, \\ Rua Marquês de São Vicente, 225, sala 210F - Gávea, Rio de Janeiro, RJ \\ 22451-900, Brazil. Tel: +55 (21) 35271078. Fax: +55 (21) 35271084. \\ Email: juliano@econ.puc-rio.br \\ FLÁVIA CHEIN \\ Department of Economics, Federal University of Juiz de Fora, Brazil. \\ Email:flavia.chein@ufif.edu.br
}

Submitted 8 April 2014; revised 19 April 2015, 23 November 2015; accepted 31 December 2015; first published online 11 April 2016

\begin{abstract}
This paper evaluates the impact of climate change on agricultural productivity. Cross-sectional variation in climate among Brazilian municipalities is used to estimate an equation in which geographical attributes determine agricultural productivity. The Intergovernmental Panel on Climate Change (IPCC) predictions based on atmosphereocean, coupled with general circulation models (for 2030-2049), are used to simulate the impacts of climate change. Our estimates suggest that global warming under the current technological standards is expected to decrease the agricultural output per hectare in Brazil by 18 per cent, with the effects on municipalities ranging from -40 to +15 per cent.
\end{abstract}

Warming of the climate system is unequivocal, as is now evident from observations of increases in global average air and ocean temperatures, widespread melting of snow and ice and rising global average sea level.

(IPCC, 2007b)

\section{Introduction}

What are the economic consequences of climate change for agriculture? What can we say about Latin American countries? According to the Fourth Assessment Report (AR4) of the IPCC (2007a), in Latin America, by mid-century, increases in temperature and associated decreases in water resources are projected to lead to the gradual replacement of tropical forest by savanna in eastern Amazonia, and semi-arid vegetation will tend to be replaced by arid-land vegetation. The report also notes that there is a risk of significant reduction in water availability for agriculture and 
energy generation. Furthermore, the productivity of some crops as well as the livestock productivity are projected to decrease. However, the AR4 also projects an increase in soybean yields in temperate zones.

This paper studies the impact of climate change on agricultural productivity in Brazil. Brazil is an important case study for many reasons. First, it is a country where agriculture plays a key role in the national economy as well as in the international markets of agricultural commodities. Second, it has a large territory with a substantial variation in agroclimatic conditions. Not only are the long-run climate indicators quite different across regions, but also the IPCC forecasts for climate change in the country vary accordingly. Third, it is still a country where a large fraction of the rural population lives below the poverty line, with potentially high exposure risk. According to the 2000 Demographic Census, 32 per cent of the rural population lives with less than one dollar per day. Notwithstanding the positive effects of the recent redistributive policies, 14 per cent and 9.5 per cent of the rural population are characterized as poor and extremely poor, respectively, in the 2012 National Household Survey. ${ }^{1}$ Finally, we have municipal-level data to conduct the study, which gives us almost 5,000 observations for the estimation.

We provide evidence on the effect of climate change on agricultural productivity in Brazil. Our approach is based on the estimation of a municipal-level production function in which input and crop choices provide the means of adaptation. The empirical strategy is based on a simple model of agricultural production with heterogeneity in labor skills. The model is estimated for a cross-section sample of Brazilian municipalities and simulated taking into account the IPCC projections for temperature and rainfall.

According to the IPCC, Brazil will experience an increase of $1.43^{\circ} \mathrm{C}$ in the average temperature and a reduction of 1.44 per cent in rainfall in the period from 2030 to 2049, which our simulations suggest will reduce the agricultural productivity by 18 per cent, with substantial heterogeneity in the different parts of the territory. The impacts on the municipalities range from -40 per cent to almost +15 per cent. The southern region of the country is expected to gain, whereas the northern and northeastern regions are expected to suffer from global warming. These results suggest that, under the current technology, climate change is likely to deepen the regional disparities across Brazilian municipalities.

Our results contribute to the literature that evaluates the consequences of climate change on agriculture in developing countries. Lybbert and Sumner (2012) argue that the development and diffusion of new practices in agriculture determine the capacity of farmers to mitigate and adapt to climate change. In this sense, we may observe difficulties in developing countries where agricultural productivity is relatively low, far from

1 The definitions of poor and extremely poor follow the definitions from the Ministry of Social Development and Bolsa Familia Program. 'Extremely poor' are those whose per capita family income is below 70 reais in 2012, and 'poor' are those whose per capita family income is above 70 reais and below 140 reais. 
the technological frontier, due to lack of infrastructure or limited capital. Poverty and vulnerability in these countries are also high. Similarly, Huang et al. (2011) emphasize that those production areas that are already less resilient will suffer the most because temperatures will rise further in tropical and semi-tropical latitudes.

Timmins (2006) suggests that the effects of climate change in Brazil are driven primarily by rising temperatures. Based on an endogenous landuse model, he finds that in the northeast of Brazil, warm temperatures become even warmer, making farming more difficult, whereas rising temperatures allow for a longer growing season in the south. He also observes that the effects of increasing rainfall are generally positive, except in the spring season in the southern region, where rainfall is already plentiful.

Sanghi and Mendelsohn (2008) also present evidence of the climate change impacts on the agricultural sector in Brazil. Their estimates range from 1 to 39 per cent of annual damages, and consider the effects of global warming on net farm income and property values. A $2{ }^{\circ} \mathrm{C}$ warming and 8 per cent precipitation increase scenario results in a loss of net farm income of $\$ 3$ billion for Brazil. It is worth noting that these estimates are based on panel data of Brazilian municipalities and take into account only uniform change scenarios within the country; in practice, changes in climate may be heterogeneous in a country the size of Brazil.

In Mexico, Cohen et al. (2012) report that natural disasters have increased in frequency and severity during the last few decades, leading to important economic losses in rural areas. The worsening climatic conditions affect the livelihoods and survival of numerous farmers that are dependent upon rain-fed agriculture, motivating migration flows.

In the case of India, Kumar and Gautam (2014) suggest that the country will face more seasonal variation in temperature. Climate change represents an important threat to agriculture and food security, especially in a country where 55 per cent of the total cultivated areas do not have access to irrigation techniques. In the same direction, Sanghi and Mendelsohn (2008) estimate a loss of 12 per cent of net farm income or $\$ 4$ billion per year in India due to $2^{\circ} \mathrm{C}$ warming and an increase of 8 per cent in precipitation.

Climate change is also expected to have severe impacts in African countries, where the economic landscape depends essentially on the dynamics of climate change. The geographical location of most African countries in lower latitudes results in dramatic impacts on agriculture, forestry, energy, tourism, coastal areas and water. Countries such as Uganda, Tunisia and others have already experienced a rise in temperatures from 1 to over $3^{\circ} \mathrm{C}$ (Abidoye and Ayodele, 2015).

Deressa and Hassan (2009), in turn, emphasize the unique role of the agriculture sector in Ethiopia, where it represents approximately 50 per cent of the gross domestic product (GDP) and supports more than 80 per cent of population employment. The exposure to climate change risk is particularly important for small farms, where farmers have limited access to technology and capital. The authors estimate that even a relatively small change in temperature during winter and summer is related to a decrease of US\$997.85 and US\$1277.28, respectively, in net revenue per hectare. Similarly, an increase in precipitation during spring increases the net revenue 
per hectare by US $\$ 225.08$, whereas increasing precipitation during winter significantly reduces net revenue by US $\$ 464.76$.

Wood and Mendelsohn (2015) also study the effects of climate change on agricultural activity in African countries. Their focus is to measure the effect of climate on agricultural net revenue on a local scale in the Fouta Djallon area of northern Guinea and southern Senegal (West Africa). The main findings show that higher temperatures and precipitation lower agricultural revenues in the economically more important rainy season, but increase revenues in the less important cool, dry season.

The remainder of the paper is organized as follows. Section 2 discusses our methodological choices based on the literature. Section 3 presents our data and section 4 provides the theoretical framework. Section 5 presents the empirical results, and concluding remarks are provided in section 6 .

\section{Alternative approaches to estimating the impact of climate change on agricultural production}

The economic literature on the consequences of climate change is organized into two strands: the production function approach and the Ricardian approach. The first approach is the most traditional. The consequences of climate change are estimated from the association between agricultural productivity and climate measures such as temperature, rainfall or greenhouse gases levels. This association is specified as a production function in which temperature, precipitation, carbon dioxide levels and other variables are inputs (Callaway et al., 1982; Adams, 1989; Adams et al., 1990). Mendelsohn et al. (1994, 2004, 2007a, 2007b) argue that these studies tend to overestimate the climate change damage because they ignore the capacity for adaptations that farmers can make in response to worse climatic conditions, such as the introduction of new crops, migration and occupational mobility. Conversely, the Ricardian approach assumes that land prices represent the expected present value of all net profits farmers can obtain from land (Mendelsohn et al., 1994; Seo and Mendelsohn, 2008a; Wood and Mendelsohn, 2015).

Empirically, instead of studying yields of specific crops, the Ricardian approach examines how climate in different places affects the net rent or the value of farmland. Mendelsohn et al. (1994) explain that by directly measuring farm prices or revenues, they can estimate the direct impacts of climate on yields of different crops as well as the indirect substitution of different inputs and several kinds of potential adaptations to any climates. According to Deressa and Hassan (2009), the most important advantage of the Ricardian model relies on its ability to take into account private adaptations. In the Ricardian model, farmers maximize profit under climate change by changing the crop mix, planting and harvesting dates, and following a host of agronomic practices.

However, Sanghi and Mendelsohn (2008) recognize some limitations of the Ricardian approach. First of all, they emphasize that transaction costs are not taken into account, making it hard to distinguish short-term resiliency from long-term adaptation. The Ricardian approach provides a 
static analysis, and it does not incorporate dynamic adjustments. Second, the Ricardian approach does not take into account irrigation possibility. That might be a strong constraint of the model because agriculture heavily depends on water availability, and the climate sensitivity of rainfed farms is indeed much higher than the climate sensitivity of irrigated farms (Kurukulasuriya et al., 2006; Sanghi and Mendelsohn, 2008; Seo and Mendelsohn, 2008a; Wang et al., 2008). Another important limitation of the Ricardian approach refers to the adoption of fixed prices. This assumption might lead to an overestimation of the benefits and damages of climate change, but it would not be trivial to incorporate price changes because they might be influenced by global prices (Sanghi and Mendelsohn, 2008).

The choice between the two approaches is not trivial. Although the Ricardian approach accounts for a broader range of possible direct and indirect effects of climate change, it is based on the assumption that the land price is determined by the expected present value of future agricultural streams. Especially for Latin American countries, land is used not only as an agricultural input but also as a source of other benefits - 'as a hedge against inflation, as an asset that can be liquidated to smooth consumption in the face of risk, as collateral for access to loans, as a tax shelter, or as a means of laundering illicit funds' (de Janvry et al., 1997). For Berry and Cline (1979), 'in countries with poorly developed capital markets, especially those with chronic inflation, landowners may prefer to hold land for speculative gain - or merely to accomplish the objective of storing of value'. Assunção (2008) presents evidence compatible with the existence of a non-agricultural component of land demand, showing that land prices in Brazil increased substantially more than rental rates during periods of high macroeconomic instability.

It is also important to note that although the Ricardian approach takes adaptation into account in its measures of climate change impacts, it is not able to give insights about how farmers adapt to new climate scenarios. In this sense, Seo and Mendelsohn (2008b) propose an alternative structural approach of the Ricardian model that explicitly models the underlying endogenous decisions by farmers. Seo $(2010,2015)$ notes that this empirical approach relies on the micro behavioral economics of global warming, that is, given the external factors such as climatic and geographic conditions, a natural resource manager is assumed to maximize the long-term profit from managing agricultural and natural resources. Thus, the theory behind this alternative model comes from a farmer's optimization decision seen as a simultaneous multiple-stage procedure. Conditional on the external factors, she/he chooses a natural resource portfolio from the full variety of portfolios available and makes decisions on the inputs and outputs of production in order to maximize the profit from the portfolio of choice. Given the profit-maximizing inputs from each farmer, it is possible to estimate the loci of profit-maximizing choices for each species across exogenous environmental factors such as temperature or precipitation (Seo and Mendelsohn, 2008b).

The structural Ricardian analysis, or the so-called G-MAP model (short for the Geographically-scaled Microeconometric model of Adapting Portfolios in response to global warming), has already been applied to a 
diversity of countries and kind of farms (specialized vs. mixed). The various papers examine crops, livestock switching and specific technology adoption (such as irrigation, fertilizer and types of seeds). Seo (2010), for example, investigates the adaptation portfolios in response to climate change using information on South American farmers. Kurukulasuriya and Mendelsohn (2008), in turn, examine the impact of climate change on primary crops grown in Africa, whereas Seo and Mendelsohn (2008b) study how African farmers adapt livestock management to different climatic conditions.

Following these structural Ricardian analyses, Di Falco and Veronesi (2013) analyse the economic implications of different climate change adaptation strategies. In addition to investigating what is most effective individual or collective strategies - the authors also identify the most successful strategies from a counterfactual analysis. To achieve their aim, Di Falco and Veronesi have access to a unique database on Ethiopian agriculture in which instruments are designed to study how farmers perceive climate change and adapt to new conditions. In this sense, these authors can map the full set of actual adaptation strategies implemented by individual farms. It is also worth mentioning that their empirical strategy takes into account important endogeneity issues that may lead to inconsistent estimations. Mainly, the authors estimate a multinomial endogenous switching regression model of climate change adaptation and crop net revenues using a two-stage procedure that produces selection-corrected net revenue.

Another debate in the literature is the use of climate versus weather information. The IPCC Fifth Assessment Report or AR5 (Cubasch et al., 2013) emphasizes that weather describes the conditions of the atmosphere at certain places and times and takes into consideration the temperature, pressure, humidity, wind, presence of clouds, precipitation and occurrence of thunderstorms, dust storms, tornados and other special phenomena. Conversely, climate, in a narrow sense, refers to the average weather or the statistical description in terms of the mean and variability of relevant quantities, temperature, precipitation and wind over a period of time ranging from months to thousands or millions of years. The World Meteorological Organization defines a period of 30 years to average these variables and then establishes climate conditions.

Although most of the papers rely on long-run cross-section variation, based on climate data, Deschênes and Greenstone (2007) argue that weather variation is orthogonal to unobserved determinants of agricultural profits, which might provide consistency gains. The authors argue that estimates of any hedonic approach may confound climate with other factors and that any bias derived from omitted variables is unknown. This occurs because unmeasured characteristics, such as soil quality and the opportunity costs of the land, are important determinants of output and land values in the agricultural sector. However, the strategy of Deschênes and Greenstone (2007) depends largely on temporary shocks and thus does not allow for adaptation mechanisms. In this sense, it is very important to clarify that 'climate change refers to a change in the state of the climate that can be identified (e.g., by using statistical tests) by changes in the mean and/or 
the variability of its properties, and that persists for an extended period, typically decades or longer' (Cubasch et al., 2013: 126).

In the same direction, Seo (2013) shows that random weather fluctuations and climatic shifts are two different meteorological events and furthermore, that they have different implications for the farmers who make adaptation decisions. According to Seo (2013), the panel fixed effects models, as estimated by Deschênes and Greenstone (2007) for example, can only reveal the impacts of random weather fluctuations on farm profits and yields, but not the impacts of climatic shifts.

One of the contributions of this paper comes from our empirical approach, which lies somewhere between the Ricardian and the production function approaches, focusing on cross-section climate variation rather than time-series weather variation. Although we explicitly specify a production function, the model from which we derive the equation for the estimation allows for adaptation in terms of the crop mix and labor mobility.

\section{Data}

We combine data from different sources. All variables and respective sources are shown in table 1.

The information about climate comes from the Climate Research Unit (CRU) at the University of East Anglia (UEA). The information on temperature and precipitation comprises a historical average over the period from 1961 to 1990 . New et al. (2002) describe the 10' latitude/longitude data set of mean monthly surface climate data over global land areas. In fact, the data set was built from an interpolation of station data set means for the period centered on 1961 to 1990, calculated from time series and added to the normals data set. It is important to note that the data were collected from a number of sources. In the case of South and Central America, personnel at the Centro Internacional de Agricultura Tropical (CIAT, International Center of Tropical Agriculture) have collated several thousand climatological means. $^{2}$

As noted by Randall et al. (2007), climate models are built on wellestablished physical principles and have been demonstrated to reproduce the observed features of recent climate and past climate changes. General circulation models (GCMs) give credible quantitative estimates of future climate change. GCMs are mathematical models of the general circulation of a planetary atmosphere or ocean and can be defined as spatially explicit dynamic models that simulate the three-dimensional climate system taking into account the laws of thermodynamics, momentum (Newton's second law of motion), conservation of mass and the ideal gas law (Wilby et al., 2009). In this kind of model, each equation is solved at discrete points on the entire surface of the Earth and for separate layers in the atmosphere, defined by a regular grid.

2 These present climate information is available for Brazil at the municipal level at www.ipeadata.gov.br. 
Table 1. Data description

\begin{tabular}{|c|c|c|}
\hline Variable & Definition & Source \\
\hline \multicolumn{3}{|l|}{ Geography } \\
\hline Rainfall & $\begin{array}{l}\text { Estimates of the average quantity } \\
\text { of water precipitation in each } \\
\text { municipality for the period of } \\
1961-1990 \text { (in mm per month) }\end{array}$ & CRU UEA \\
\hline Temperature & $\begin{array}{l}\text { Estimates of the average tempera- } \\
\text { ture in each municipality for the } \\
\text { period of } 1961-1990\left(\text { in }{ }^{\circ} \mathrm{C}\right)\end{array}$ & CRU UEA \\
\hline Soil & $\begin{array}{l}\text { A set of dummy variables } \\
\text { indicating the kind of soil }\end{array}$ & EMBRAPA \\
\hline \multicolumn{3}{|l|}{ Productivity } \\
\hline $\begin{array}{l}\text { Agricultural } \\
\text { output per ha }\end{array}$ & $\begin{array}{l}\text { Mean of the total value of } \\
\text { agricultural production per } \\
\text { planted area from 1997-2006 }\end{array}$ & PAM - IBGE \\
\hline $\begin{array}{l}\text { Agricultural } \\
\text { output per } \\
\text { worker }\end{array}$ & $\begin{array}{l}\text { Mean of the total value of } \\
\text { agricultural production from } \\
\text { 1997-2006 for the total number } \\
\text { of workers in the agricultural } \\
\text { sector in } 2000\end{array}$ & $\begin{array}{l}\text { PAM and Demo- } \\
\text { graphic Census, } \\
2000 \text { - IGBE }\end{array}$ \\
\hline $\begin{array}{l}\text { Average agri- } \\
\text { cultural } \\
\text { wages }\end{array}$ & $\begin{array}{l}\text { Mean of wages paid in the } \\
\text { agricultural sector in } 2000\end{array}$ & $\begin{array}{l}\text { Demographic Census, } \\
2000 \text { - IGBE }\end{array}$ \\
\hline \multicolumn{3}{|l|}{ GCM Forecast } \\
\hline $\begin{array}{l}\text { Average change } \\
\text { in temperature }\end{array}$ & $\begin{array}{l}\text { Forecast of temperature change for } \\
\text { the period between } 2030-2049 \\
\left.\text { based on AOGCMs (in }{ }^{\circ} \mathrm{C}\right)\end{array}$ & IPCC (WMO/UNEP) \\
\hline $\begin{array}{l}\text { Average change } \\
\text { in rainfall }\end{array}$ & $\begin{array}{l}\text { Forecast of average per cent } \\
\text { changes in rainfall for the period } \\
\text { between 2030-2049 based on } \\
\text { AOGCMs }\end{array}$ & IPCC (WMO/UNEP) \\
\hline
\end{tabular}

Source: Authors' elaboration.

According to the IPCC (2007b), the atmosphere-ocean coupled GCMs (AOGCMs) are the most comprehensive climate models because they include dynamical components to describe atmospheric, ocean, land surface processes, sea ice and other components. In spite of the fact that there has been significant progress since the first IPCC report and improvements in the resolution of AOGCMs, it is worth noting that, in many cases, it is insufficient to capture the fine-scale structure of climatic variables in many regions. In such cases, the key is the regional climate models based on the empirical downscaling techniques (Christensen et al., 2007).

Even though the CRU also has information about climate projections, we obtain the data from the IPCC, a scientific organization set up by the World Meteorological Organization (WMO) and the United Nations 
Table 2. Summary statistics

\begin{tabular}{lrrrr}
\hline & Mean & S.d. & Min & Max \\
\hline Temperature $\left({ }^{\circ} \mathrm{C}\right)$ & 22.73 & 2.99 & 14 & 28.04 \\
Rainfall $($ mm per month) & 116.11 & 36.63 & 28.87 & 282.43 \\
Average temperature change forecast $\left({ }^{\circ} \mathrm{C}\right)$ & 1.43 & 0.23 & 0.92 & 1.95 \\
Average rainfall change forecast $(\%)$ & -1.44 & 3.15 & -8.24 & 5.47 \\
Agricultural output per ha $(\mathrm{R} \$ 2006)$ & 3.07 & 2.62 & 0 & 37.16 \\
Agricultural output per worker $(\mathrm{R} \$ 2006)$ & 1.88 & 4 & 0 & 55.31 \\
Average agricultural wages $(\mathrm{R} \$ 2000)$ & 238.12 & 215.38 & 0 & 4083.21 \\
\hline
\end{tabular}

Source: Authors' elaboration.

Environment Programme (UNEP). ${ }^{3}$ Our choice is based on four reasons. First of all, the models from the CRU could be considered out of date because they are based on the IPCC Third Assessment Report (TAR), not the most recent. There were significant improvements in the climate change estimates between the TAR and the Fourth Assessment Report (AR4). Second, they use only four GCMs. Third, there is false precision because the GCMs that the data set is based on all have a resolution larger than 2 degrees. Finally, only time slices for the end of the century are available.

The future scenario variables used in this paper comprise temperature and rainfall forecasts computed by the IPCC. The forecasts are based on AOGCMs and cover the period from 2030 to 2049 and consider the scenario A1B. The appendix presents detailed information regarding these models. The data are available from the IPCC as grid or raster data, with 2 degrees resolution. The forecast information for Brazil at the municipal level was built using geoprocessing tools ${ }^{4}$ that allow us to combine the raster data and coordinates of each Brazilian municipal seat.

The soil types were collected by Empresa Brasileira de Pesquisa Agropecuária (EMBRAPA, Brazilian Agricultural Research Institute). These variables consist of a set of 12 binary variables indicating the types of soil present in a $0.1^{\circ}$ radius of a circumference around the center of the municipality.

Finally, the geographical coordinates (longitude, latitude and altitude) of each municipality are obtained from the Brazilian Census Bureau (IBGE), as well as our outcome variables. The agricultural output and agricultural output per hectare are averaged for the years 1997 to 2006, considering data from the Municipal Agricultural Survey (PAM) collected annually by the IBGE. We decided to consider averages to smooth out idiosyncratic shocks and thus characterize the agricultural productivity of each municipality on a longer term.

The descriptive statistics of the data are reported in table 2.

The temperatures in our sample of Brazilian municipalities range from $14^{\circ} \mathrm{C}$ to $28^{\circ} \mathrm{C}$. Panel (a) of figure 1 shows that the highest average

${ }^{3}$ We are thankful to Michael Westphal for sharing the data and helping us manage them.

4 These tools are available in the software ArcGIS. 
(a) Average temperature in Brazilian municipalities 1961-1990
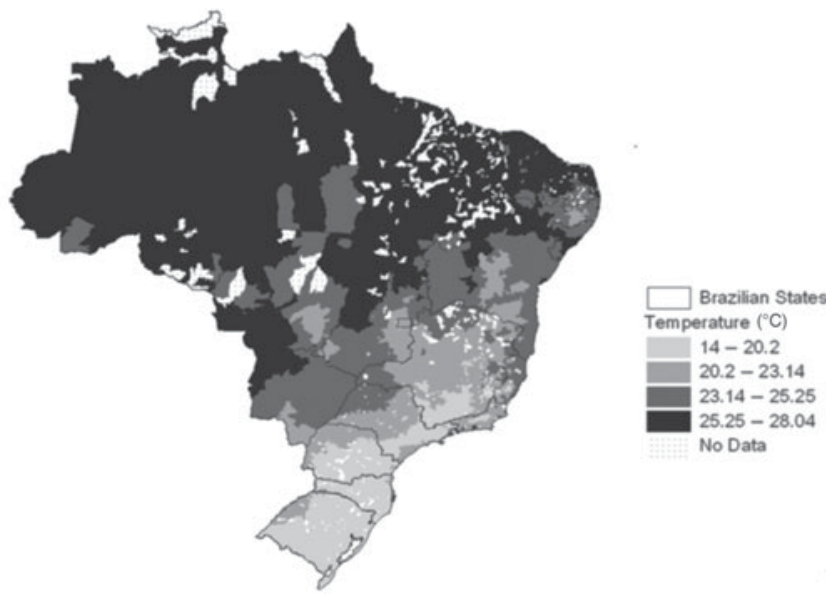

$\infty 00$

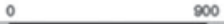

1800 Miles

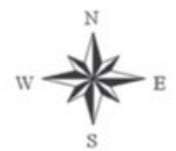

(b)

Average rainfall in Brazilian municipalities

1961-1990

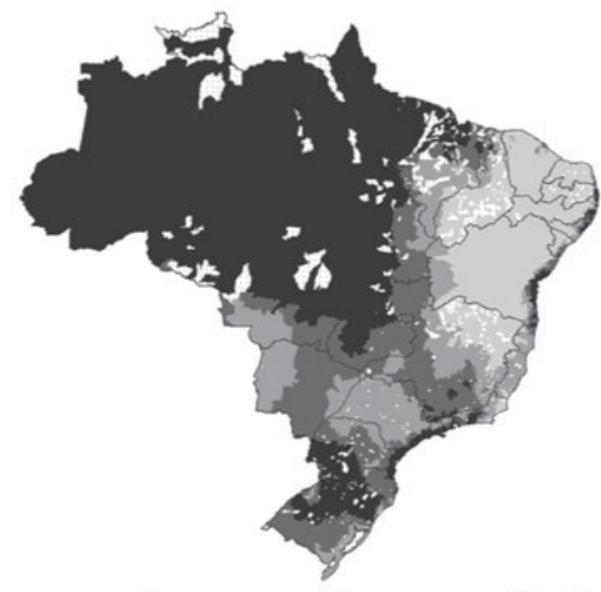

1800 Mlles

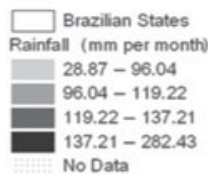

900

900

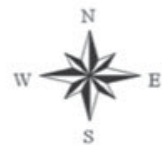

Figure 1. Average temperature and rainfall across Brazilian municipalities

temperature levels appear at municipalities in the North and Northeast regions, which are the less developed regions in the country.

The rainfall levels, as shown in table 2, range from approximately 29 to $280 \mathrm{~mm}$ per month. Panel (b) of figure 1 shows the geographical distribution. The Northeast region presents a large number of municipalities with low levels of precipitation. 
(a)

\author{
Temperature change \\ in Brazilian municipalities
}
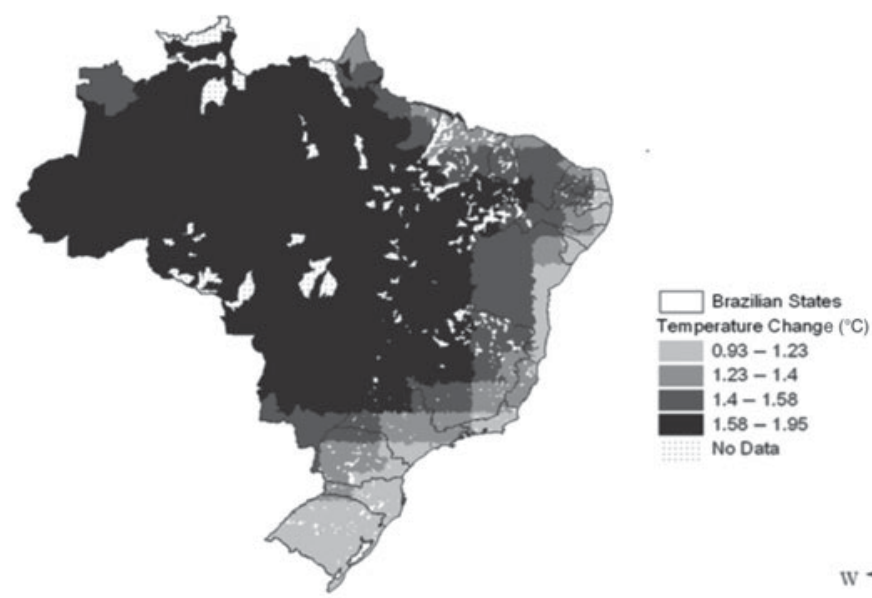

900

900

1800 Miles

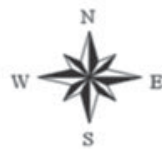

(b)

Rainfall change in

Brazilian municipalities
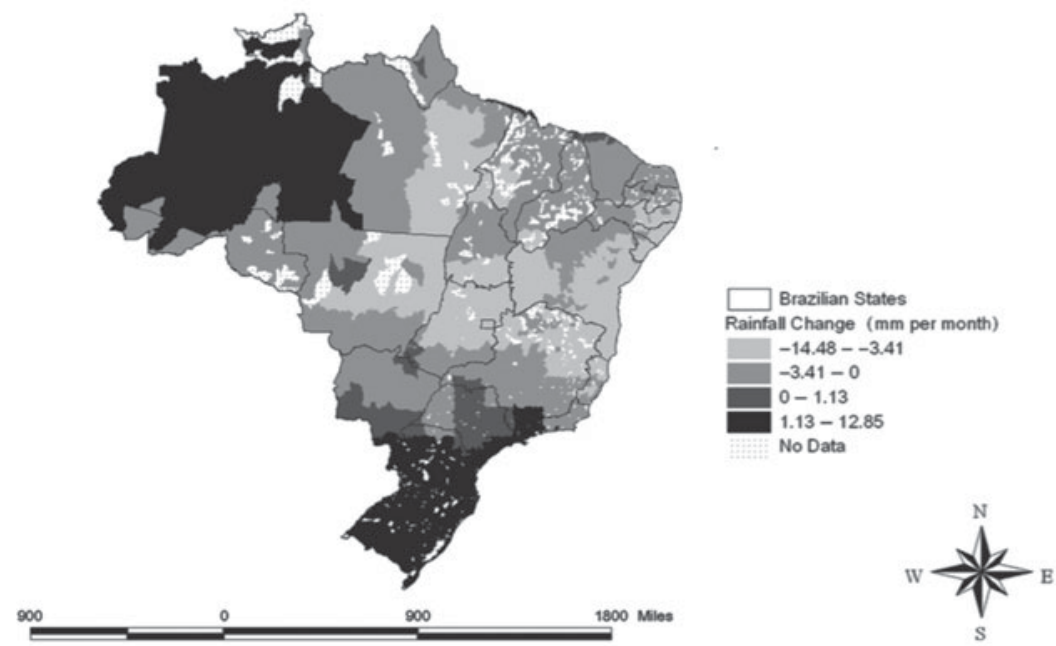

Source: Authors' Elaboration based on IPCC forecast data from AR4

Figure 2. Predicted changes in temperature and rainfall across Brazilian municipalities

The climate change forecasts for Brazil, derived from the IPPC projections, are depicted in figure 2. Panel (a) of figure 2 shows that the temperature is expected to increase more intensely in the North and Central-West 
regions. The rainfall predictions suggest an increase in precipitation in the South region and Amazônia, and a reduction in precipitation in the Central and Northeast regions (panel (b) of figure 2).

\section{Theoretical framework}

Consider the following Cobb-Douglas aggregate production function for each municipality $i$ :

$$
Y_{i}=A_{i} T_{i}^{1-\alpha-\beta} K_{i}^{\alpha} L_{i}^{\beta} \exp \left(\varepsilon_{i}\right), \quad i=1, \ldots, M,
$$

where $Y_{i}$ represents the total output with price normalized to $1 ; T_{i}$ is the available area; $K_{i}$ and $L_{i}$ represent the amount of non-labor and labor input; $A_{i}$ is a technological factor; and $\varepsilon_{i}$ is an error term accounting for idiosyncratic determinants of the output, such as climatic shocks.

We also assume that labor is heterogeneous - agricultural workers have different skills. A worker of type $\theta \in[0,1]$ has productivity represented by $\phi(\theta)$ where $\phi^{\prime}>0$ and $\phi(0)=1$. Then, the total labor input employed in a municipality $i$ is given by:

$$
L_{i}=\int_{0}^{1} \phi_{i}(\theta) L_{i}(\theta) d \theta,
$$

where $L_{i}(\theta)$ is the number of workers of type $\theta$ employed in the production.

Consider now a competitive environment with no externality. For any arbitrary plot size $T_{i}$, we assume that farmers in municipality $i$ maximize the expected profit given the observed climate conditions $C_{i}$ :

$$
\begin{array}{rl}
\max _{K_{i}, L_{i}} & E\left(A_{i} T_{i}^{1-\alpha-\beta} K_{i}^{\alpha}\left(\int_{0}^{1} \phi_{i}(\theta) L_{i}(\theta) d \theta\right)^{\beta} \exp \left(\varepsilon_{i}\right)-r_{i} K_{i}\right. \\
& \left.-\int_{0}^{1} w_{i}(\theta) L_{i}(\theta) d \theta \mid C_{i}\right) .
\end{array}
$$

The first-order conditions for $K_{i}^{*}$ and $L_{i}^{*}(\theta), \theta \in[0,1]$ are given by:

$$
\begin{aligned}
\alpha E\left(\frac{Y_{i}^{*}}{K_{i}^{*}} \mid C_{i}\right) & =r_{i}, \\
\beta E\left(\frac{Y_{i}^{*}}{L_{i}^{*}} \mid C_{i}\right) \phi_{i}(\theta) & =w_{i}(\theta), \quad \text { for all } \theta \in[0,1] .
\end{aligned}
$$

The system (3)-(4) shows that the expected marginal revenue is equal to the marginal cost of each input. Moreover, equation (4) implies that $\frac{w_{i}(\theta)}{\phi_{i}(\theta)}=$ $\frac{w_{i}\left(\theta^{\prime}\right)}{\phi_{i}\left(\theta^{\prime}\right)}$ for all $\theta, \theta^{\prime} \in[0,1]$. Thus, we have that

$$
w_{i}(\theta)=\phi_{i}(\theta) w_{i}(0) .
$$


Equation (5) shows that the wage schedule is completely determined by the baseline wage $w_{i}(0)$ and the productivity function $\phi_{i}(\theta)$ because workers of different abilities are substitutes. The optimal amount of non-labor and labor inputs is given by

$$
\begin{aligned}
& K_{i}^{*}=T_{i}\left(\frac{A_{i}}{r_{i}^{1-\beta} w_{i}(0)^{\beta}} \alpha^{1-\beta} \beta^{\beta} E\left(\exp \left(\varepsilon_{i}\right) \mid C_{i}\right)\right)^{\frac{1}{1-\alpha-\beta}} \\
& L_{i}^{*}=\int_{0}^{1} \phi_{i}(\theta) L_{i}^{*}(\theta) d \theta=T_{i}\left(\frac{A_{i}}{r_{i}^{\alpha} w_{i}(0)^{1-\alpha}} \alpha^{\alpha} \beta^{1-\alpha} E\left(\exp \left(\varepsilon_{i}\right) \mid C_{i}\right)\right)^{\frac{1}{1-\alpha-\beta}} .
\end{aligned}
$$

Finally, the agricultural output for the municipality with land endowment of $T_{i}$ is given by

$$
Y_{i}^{*}=T_{i}\left(\frac{A_{i}}{r_{i}^{\alpha} w_{i}(0)^{\beta}} \alpha^{\alpha} \beta^{\beta}\right)^{\frac{1}{1-\alpha-\beta}} E\left(\exp \left(\varepsilon_{i}\right) \mid C_{i}\right)^{\frac{\alpha+\beta}{1-\alpha-\beta}} \exp \left(\varepsilon_{i}\right)
$$

In addition to the agricultural sector, we also assume there is a subsistence activity in the economy that provides a very low income $\bar{w}$ which is typically below the poverty and indigence levels of income. This subsistence activity does not require any special skill and, therefore, is available to everyone in the economy. As a consequence, it establishes a lower bound for the baseline wage rate, i.e., $w_{i}(0) \geq \bar{w}$. This structure is commonly used in the occupational choice literature. ${ }^{5}$

We now adopt three assumptions to drive our empirical analysis.

Assumption A1. There is perfect capital mobility across municipalities: $r_{i}=r$ for all $i=1, \ldots, M$.

Assumption A2. The total factor productivity is determined by a constant $A$ and an idiosyncratic term $v_{i}$ across municipalities that is independent from $C_{i}: A_{i}=A \exp \left(v_{i}\right)$.

Assumption A3. The number of unskilled workers (those with type $\theta=0$ ) is large enough to assure that $w_{i}(0)=\bar{w}$ for all $i=1, \ldots, M$.

Assumptions A1 and A2 determine that all municipalities face the same capital return and do not present systematic technological differences. Assumption A3 captures the fact that most of the Brazilian municipalities have a significant fraction of the population living in poverty or even indigence conditions.

Assumption A3 states that the subsistence activity yields the same income in all municipalities. ${ }^{6}$ This assumption is also adopted in

5 See, for instance, Banerjee and Newman (1993) and Galor and Zeira (1993).

${ }^{6}$ Actually, the variation of the average income of the poor across municipalities is substantially lower than the variation of the per capita income. The 10th and 
Table 3. Effect of climate on agricultural output per hectare

Dependent Variable: agricultural output per hectare (in log)

\begin{tabular}{lcc}
\hline & $(1)$ & $(2)$ \\
\hline Average temperature & $0.640^{* * *}$ & $0.506^{* * *}$ \\
& $(0.056)$ & $(0.059)$ \\
Average temperature squared & $-0.016^{* * *}$ & $-0.014^{* * *}$ \\
& $(0.001)$ & $(0.001)$ \\
Average precipitation & $0.019^{* * *}$ & $0.015^{* * *}$ \\
& $(0.001)$ & $(0.002)$ \\
Average precipitation squared & $-0.000^{* * *}$ & $-0.000^{* * *}$ \\
& $(0.000)$ & $(0.000)$ \\
Soil dummies & No & Yes \\
Constant & $-7.091^{* * *}$ & $-4.978^{* * *}$ \\
& $(0.640)$ & $(0.699)$ \\
Observations & 4948 & 4948 \\
$R$ squared & 0.32 & 0.42 \\
\hline
\end{tabular}

Note: Standard errors in parentheses. ${ }^{*}$ significant at $10 \%$;

** significant at $5 \%$; *** significant at $1 \%$.

Source: Authors' elaboration.

Jeong and Townsend $(2007,2008)$. As a result, it means that migration (and its effect on the labor market) does not affect our analysis of agricultural productivity in our case. As shown by equation (5), the whole wage schedule in this case is completely determined by the productivity parameters $\phi_{i}(\theta)$ and the subsistence wage $\bar{w}$.

Under assumptions A1-A3, the direct effect of climate change on the agricultural output per hectare can be obtained by the following regression:

$$
\ln \left(\frac{Y_{i}}{T_{i}}\right)=\gamma_{0}+\gamma\left(C_{i}\right)+u_{i}
$$

where $\gamma_{0} \equiv \frac{1}{1-\alpha-\beta} \ln \left(\frac{A}{r^{\alpha} \bar{w}^{\beta}} \alpha^{\alpha} \beta^{\beta}\right), \quad \gamma\left(C_{i}\right) \equiv \frac{\alpha+\beta}{1-\alpha-\beta} \ln \left(E\left(\exp \left(\varepsilon_{i}\right) \mid C_{i}\right)\right)$ and $u_{i}=\varepsilon_{i}+v_{i}$. Specification (9) captures all of the direct effects of climate on agricultural productivity. Our dependent variable in this first exercise is the aggregate agricultural output per hectare for each municipality. Thus, we can interpret crop choice as embedded in the input choice. However, this analysis with assumptions A1-A3 ignores the effects of climate change that work through prices and technology adaptation.

90th percentile for the average income of the poor are $\mathrm{R} \$ 53$ and $\mathrm{R} \$ 61$, respectively, whereas the same indicators for per capita income are $\mathrm{R} \$ 199$ and $\mathrm{R} \$ 640$, respectively. 

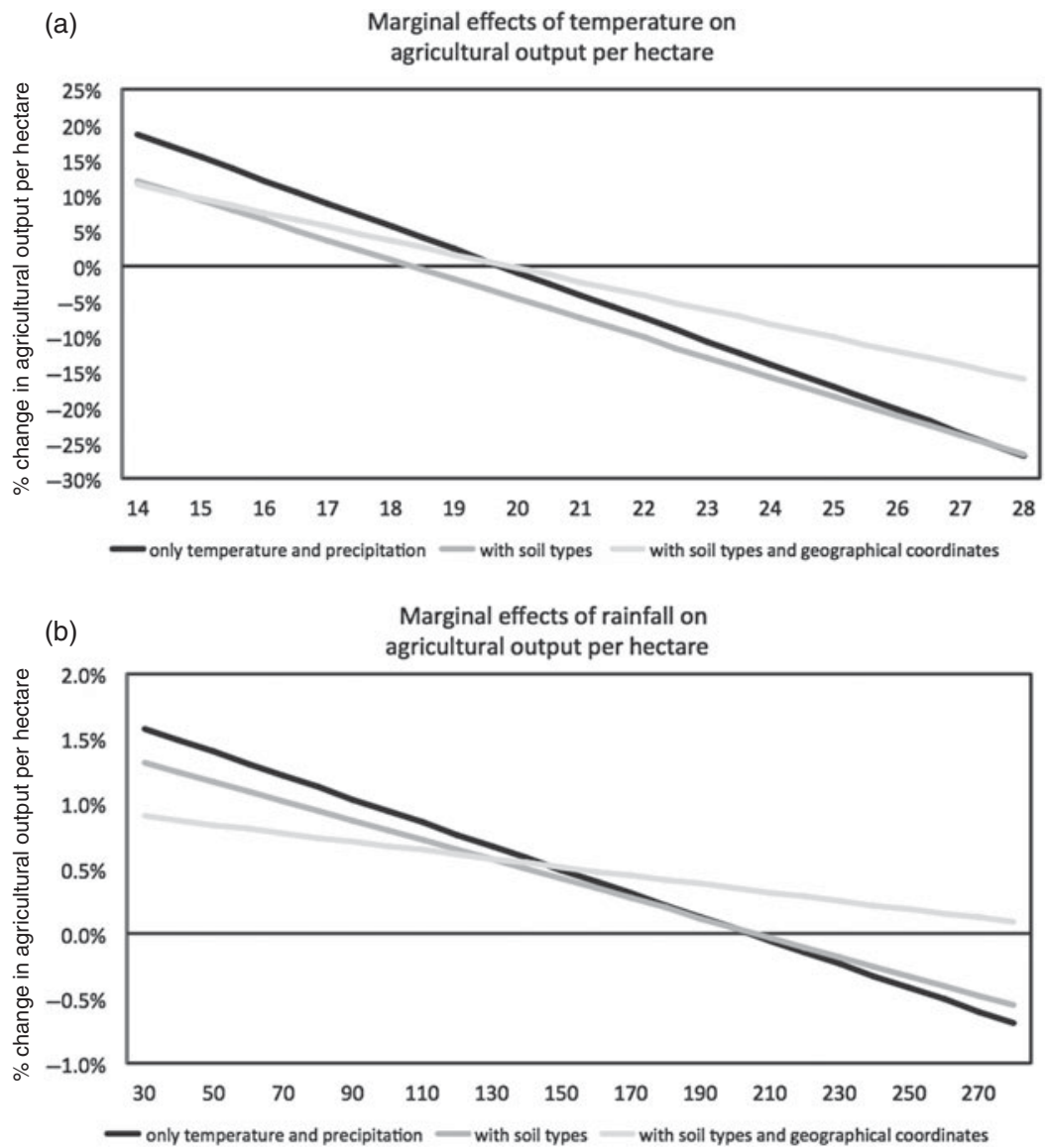

Figure 3. Marginal effect of temperature and rainfall

\section{Empirical characterization}

We now estimate (9) using cross-section variation from the Brazilian municipalities. The vector $C_{i}$ contains the available and observed variables regarding climate conditions for municipality $i$ : temperature, rainfall and soil types. For the cases of temperature and precipitation, we consider a quadratic specification following Mendelsohn et al. (1994). The soil information is introduced as a set of dummy variables indicating each of the predominant soil types in each municipality.

In the estimation of the effect of climate change on agricultural productivity, through equation (9), it is important to notice that we only have simulated data for temperature and precipitation. We do not have forecasts for soil types, although soil conditions might be affected, in principle, by climate change. If we introduce it into the regression and keep it constant for the simulation, we may underestimate the effect of climate change on agricultural productivity. Conversely, part of the soil conditions are not 


\section{Effects of climate change on agricultural output per ha in Brazilian municipalities}
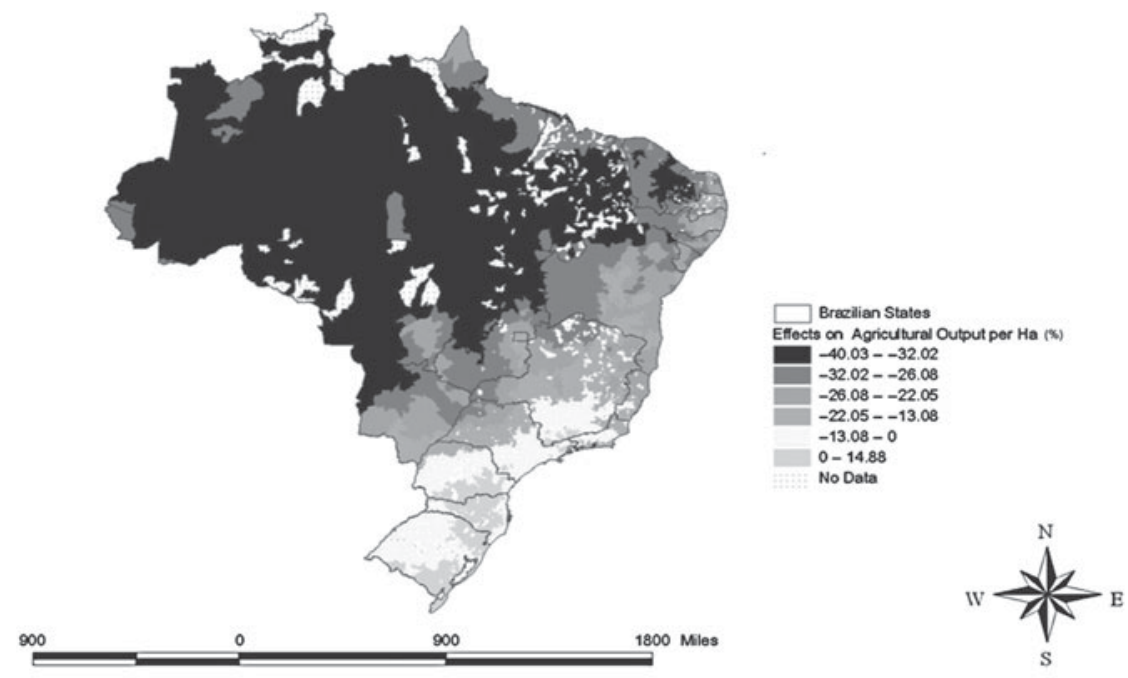

Source: Authors' Elaboration

Figure 4. Effects of climate change on agricultural output

affected by climate and, therefore, this can improve our estimates. Thus, we report our main results with and without conditioning on soil conditions. The results are reported in table 3 . A comparison of the marginal effects of temperature and rainfall are presented in figure 3.

As expected, the importance of temperature and rainfall decreases when we include soil dummies (in column 2) and geographical locations (in column 3). The largest change is observed with the latitude and longitude coordinates. The differences between the marginal effects with and without soil types are comparatively less important, especially if we restrict our attention to the relevant values - more than $20^{\circ} \mathrm{C}$ and less than $150 \mathrm{~mm}$ per month. Hereafter, we take the specification with soil types (column 2) as our preferred equation for agricultural productivity.

\subsection{Simulations}

The impact of climate change on agricultural productivity is estimated through equation (9). We now consider the vector of climate information for each municipality $C_{i}$ as containing information on temperature, rainfall and soil types. Then, we use the IPCC projection for temperature and rainfall for the period of 2030 to 2049 to build a different climate vector for each municipality, $\hat{C}_{i}$. The expected agricultural output per hectare in each municipality, under the new climate conditions, is given by:

$$
E\left(\ln \left(\frac{Y_{i}}{T_{i}}\right)\right)=\hat{\gamma}_{0}+\hat{\gamma}\left(\hat{C}_{i}\right)
$$


Table 4. Simulated effects of climate change on agricultural output her hectare

\begin{tabular}{|c|c|c|c|c|c|c|c|c|c|c|c|c|}
\hline \multirow{3}{*}{$\begin{array}{l}\text { Brazilian states } \\
\text { Acre }\end{array}$} & \multicolumn{2}{|c|}{$\begin{array}{l}\text { Rainfall } \\
\text { change }\end{array}$} & \multicolumn{2}{|c|}{$\begin{array}{l}\text { Temperature } \\
\text { change }\end{array}$} & \multicolumn{2}{|c|}{$\begin{array}{c}\text { Agricultural } \\
\text { output per hectare }\end{array}$} & \multicolumn{2}{|c|}{$\begin{array}{l}\text { Forecast agricultural } \\
\text { output per hectare }\end{array}$} & \multirow{3}{*}{$\begin{array}{c}\begin{array}{c}\text { Per cent } \\
\text { change }\end{array} \\
\text { Mean } \\
-34.3 \%\end{array}$} & \multirow{2}{*}{\multicolumn{3}{|c|}{$\begin{array}{l}95 \% \text { confidence interval } \\
\text { of climate change effect }\end{array}$}} \\
\hline & \multirow{2}{*}{$\begin{array}{c}\text { Mean } \\
-0.22 \%\end{array}$} & \multirow{2}{*}{$\begin{array}{c}\mathrm{Sd} \\
0.87 \%\end{array}$} & \multirow{2}{*}{$\begin{array}{l}\text { Mean } \\
7.09 \%\end{array}$} & \multirow{2}{*}{$\begin{array}{c}\mathrm{Sd} \\
0.24 \%\end{array}$} & \multirow{2}{*}{$\begin{array}{c}\text { Mean } \\
1,713.15\end{array}$} & \multirow{2}{*}{$\begin{array}{c}\mathrm{Sd} \\
280.39\end{array}$} & \multirow{2}{*}{$\begin{array}{c}\text { Mean } \\
1,130.60\end{array}$} & \multirow{2}{*}{$\begin{array}{c}\mathrm{Sd} \\
216.99\end{array}$} & & & & \\
\hline & & & & & & & & & & $-35.4 \%$ & - & $-33.1 \%$ \\
\hline Alagoas & $-6.48 \%$ & $0.77 \%$ & $4.98 \%$ & $0.43 \%$ & $1,475.15$ & 577.32 & $1,116.40$ & 451.78 & $-24.9 \%$ & $-25.3 \%$ & - & $-24.4 \%$ \\
\hline Amapá & $-0.78 \%$ & $0.26 \%$ & $5.52 \%$ & $0.39 \%$ & $1,611.04$ & 284.97 & $1,145.57$ & 207.29 & $-28.9 \%$ & $-30.6 \%$ & - & $-27.2 \%$ \\
\hline Amazonas & $2.22 \%$ & $1.32 \%$ & $6.73 \%$ & $0.32 \%$ & $1,643.05$ & 389.60 & $1,056.27$ & 276.16 & $-36.0 \%$ & $-36.6 \%$ & - & $-35.4 \%$ \\
\hline Bahia & $-6.30 \%$ & $1.12 \%$ & $5.94 \%$ & $0.74 \%$ & $1,443.93$ & 692.19 & $1,076.41$ & 521.77 & $-25.6 \%$ & $-25.9 \%$ & _- & $-25.3 \%$ \\
\hline Ceará & $-1.82 \%$ & $1.29 \%$ & $5.65 \%$ & $0.53 \%$ & 724.24 & 264.41 & 506.90 & 200.09 & $-30.6 \%$ & $-30.9 \%$ & - & $-30.2 \%$ \\
\hline Distrito Federal & $-3.59 \%$ & - & $8.16 \%$ & - & $2,137.31$ & - & $1,722.67$ & - & $-19.4 \%$ & & - & \\
\hline Espírito Santo & $-4.12 \%$ & $1.08 \%$ & $5.83 \%$ & $0.46 \%$ & $2,142.64$ & 849.81 & $1,730.17$ & 626.36 & $-18.6 \%$ & $-20.1 \%$ & - & $-17.0 \%$ \\
\hline Goiás & $-1.91 \%$ & $1.34 \%$ & $7.63 \%$ & $0.27 \%$ & $1,666.14$ & 191.96 & $1,221.83$ & 182.52 & $-26.9 \%$ & $-27.4 \%$ & - & $-26.5 \%$ \\
\hline Maranhão & $-2.03 \%$ & $0.87 \%$ & $5.90 \%$ & $0.55 \%$ & $1,054.22$ & 250.44 & 703.17 & 171.88 & $-33.4 \%$ & $-33.7 \%$ & - & $-33.0 \%$ \\
\hline Mato Grosso & $-2.12 \%$ & $1.06 \%$ & $7.59 \%$ & $0.30 \%$ & $1,638.90$ & 228.86 & $1,123.48$ & 212.40 & $-31.8 \%$ & $-32.6 \%$ & _- & $-31.1 \%$ \\
\hline Mato Grosso do Sul & $0.35 \%$ & $0.50 \%$ & $6.95 \%$ & $0.35 \%$ & $1,652.26$ & 192.08 & $1,276.86$ & 194.43 & $-23.0 \%$ & $-23.8 \%$ & - & $-22.2 \%$ \\
\hline Minas Gerais & $-1.42 \%$ & $1.67 \%$ & $7.27 \%$ & $0.54 \%$ & $2,026.57$ & 486.93 & $1,718.50$ & 533.94 & $-16.6 \%$ & $-17.1 \%$ & - & $-16.0 \%$ \\
\hline Paraiba & $-4.27 \%$ & $1.59 \%$ & $5.43 \%$ & $0.58 \%$ & $1,139.93$ & 965.85 & 855.87 & 727.75 & $-25.4 \%$ & $-25.9 \%$ & - & $-24.9 \%$ \\
\hline Paraná & $1.87 \%$ & $1.09 \%$ & $6.87 \%$ & $0.35 \%$ & $1,885.75$ & 591.34 & $1,780.80$ & 638.22 & $-6.5 \%$ & $-7.1 \%$ & - & $-5.8 \%$ \\
\hline Pará & $-1.88 \%$ & $1.05 \%$ & $6.39 \%$ & $0.69 \%$ & $1,552.14$ & 230.04 & $1,030.95$ & 169.38 & $-33.7 \%$ & $-34.2 \%$ & - & $-33.2 \%$ \\
\hline Pernambuco & $-6.15 \%$ & $1.62 \%$ & $5.54 \%$ & $0.63 \%$ & $1,196.86$ & 758.83 & 913.84 & 596.42 & $-24.8 \%$ & $-25.4 \%$ & - & $-24.2 \%$ \\
\hline Piauí & $-2.39 \%$ & $0.84 \%$ & $6.04 \%$ & $0.36 \%$ & 777.13 & 291.84 & 515.15 & 199.44 & $-33.9 \%$ & $-34.3 \%$ & - & $-33.6 \%$ \\
\hline Rio Grande do Norte & $-2.83 \%$ & $1.22 \%$ & $5.01 \%$ & $0.43 \%$ & 735.17 & 302.84 & 531.92 & 231.50 & $-28.3 \%$ & $-28.9 \%$ & - & $-27.7 \%$ \\
\hline Rio Grande do Sul & $3.23 \%$ & $0.25 \%$ & $5.70 \%$ & $0.35 \%$ & $2,246.95$ & 545.84 & $2,186.63$ & 541.34 & $-2.7 \%$ & $-3.0 \%$ & - & $-2.4 \%$ \\
\hline Rio de Janeiro & $-0.85 \%$ & $0.87 \%$ & $5.13 \%$ & $0.58 \%$ & $3,022.00$ & 1251.63 & $2,591.53$ & $1,080.06$ & $-14.1 \%$ & $-14.8 \%$ & - & $-13.4 \%$ \\
\hline Rondônia & $-1.46 \%$ & $0.39 \%$ & $7.44 \%$ & $0.09 \%$ & $1,491.46$ & 278.39 & 937.84 & 175.37 & $-37.1 \%$ & $-37.4 \%$ & _- & $-36.8 \%$ \\
\hline Roraima & $0.47 \%$ & $0.99 \%$ & $7.02 \%$ & $0.22 \%$ & $1,642.43$ & 378.49 & $1,075.05$ & 272.16 & $-34.9 \%$ & $-36.8 \%$ & _- & $-33.0 \%$ \\
\hline Santa Catarina & $2.94 \%$ & $0.20 \%$ & $6.43 \%$ & $0.64 \%$ & $2,210.27$ & 661.24 & $2,230.35$ & 690.92 & $1.0 \%$ & $0.5 \%$ & - & $1.6 \%$ \\
\hline Sergipe & $-6.26 \%$ & $0.67 \%$ & $4.81 \%$ & $0.28 \%$ & $1,007.83$ & 393.59 & 752.01 & 291.37 & $-25.3 \%$ & $-25.6 \%$ & - & $-25.0 \%$ \\
\hline São Paulo & $0.05 \%$ & $0.39 \%$ & $6.76 \%$ & $0.38 \%$ & $1,938.47$ & 399.36 & $1,625.03$ & 423.53 & $-16.9 \%$ & $-17.4 \%$ & - & $-16.4 \%$ \\
\hline Tocantins & $-2.82 \%$ & $1.26 \%$ & $6.69 \%$ & $0.15 \%$ & $1,122.36$ & 210.48 & 717.64 & 143.34 & $-36.2 \%$ & $-36.5 \%$ & - & $-35.8 \%$ \\
\hline \multicolumn{13}{|l|}{ Macro regions } \\
\hline North & $-1.49 \%$ & $1.64 \%$ & $6.71 \%$ & $0.65 \%$ & $1,485.87$ & 308.49 & 968.81 & 217.97 & $-35.0 \%$ & $-35.3 \%$ & - & $-34.7 \%$ \\
\hline Northeast & $-4.65 \%$ & $2.33 \%$ & $5.70 \%$ & $0.70 \%$ & $1,161.82$ & 654.85 & 851.34 & 504.43 & $-27.7 \%$ & $-27.9 \%$ & - & $-27.5 \%$ \\
\hline Central-West & $-1.54 \%$ & $1.46 \%$ & $7.47 \%$ & $0.41 \%$ & $1,654.57$ & 213.85 & $1,192.09$ & 213.89 & $-28.3 \%$ & $-28.8 \%$ & - & $-27.8 \%$ \\
\hline Southeast & $-0.77 \%$ & $1.56 \%$ & $6.86 \%$ & $0.63 \%$ & $2,005.68$ & 524.85 & $1,685.64$ & 519.67 & $-16.8 \%$ & $-17.2 \%$ & - & $-16.5 \%$ \\
\hline South & $2.54 \%$ & $1.02 \%$ & $6.33 \%$ & $0.68 \%$ & $2,068.67$ & 606.06 & $1,994.51$ & 639.11 & $-4.2 \%$ & $-4.5 \%$ & - & $-3.8 \%$ \\
\hline Brazil & $-0.71 \%$ & $3.07 \%$ & $6.57 \%$ & $0.87 \%$ & $1,751.90$ & 636.53 & $1,474.52$ & 678.73 & $-18.2 \%$ & $-18.6 \%$ & - & $-17.9 \%$ \\
\hline
\end{tabular}

Note: The reported values are the weighted average at the state level of forecasts and simulated climate change effects at the municipal level. Simulated climate change effects at the municipal level and their confidence interval are available upon request to the authors.

Source: Authors' elaboration. 
where $\hat{\gamma}_{0}$ and $\hat{\gamma}(\cdot)$ correspond to the estimates reported in column 2 of table 3 .

The difference in agricultural productivity due to climate change can be computed by

$$
\Delta E\left(\ln \left(\frac{Y_{i}}{T_{i}}\right)\right)=\left(\hat{\gamma}_{0}+\hat{\gamma}\left(\hat{C}_{i}\right)\right)-\left(\hat{\gamma}_{0}+\hat{\gamma}\left(C_{i}\right)\right),
$$

where the first term is the expected agricultural output per hectare in each municipality under new climate conditions $\left(\hat{C}_{i}\right)$ and the second term is the expected agricultural output per hectare in each municipality under present climate conditions $\left(C_{i}\right)$.

From the predicted agricultural output per hectare, we can obtain the percentage change in agricultural productivity given by the climate change in each municipality. A map with the impact for all Brazilian municipalities is depicted in figure 4 , and the results aggregated for Brazilian states, macro regions and the whole country are presented in table 4.

Considering the whole country, the increase of 6.57 per cent in the average temperature along with the decrease of 0.71 per cent in rainfall leads to a reduction of 18 per cent in the agricultural productivity. We can also see that the impact is very heterogeneous in the country. The state-level impacts range from -37 per cent in Rondônia State to 1 per cent in Santa Catarina. The impact on the North is substantially higher than the impact on the South; such results coincide with the results of Timmins (2006). These estimates are also in accordance with previous results by Sanghi and Mendelsohn (2008), which estimate annual damages in the agricultural sector in Brazil from 1 to 39 per cent.

An underlying assumption of the exercise above is the absence of technological responses to the new climate conditions. The results are predicted using the imputation of climate forecasts on current agricultural technological status. However, the cross-section comparisons across municipalities or states reveal how intense the technological gains should be to mitigate the impact of climate change in each municipality or state.

The results from the simulations suggest that climate change is likely to increase regional disparities across Brazilian states and municipalities because the most affected areas are those that already show lower productivity. The need for adaptation measures is higher in the poorer areas of Brazil.

\section{Conclusion}

The paper investigates the impact of climate change on agricultural productivity in Brazil. We present a simple model to guide the empirical analysis. The model is estimated and simulated taking into account IPCC predictions about temperature and rainfall. The results suggest that global warming is expected to generate significant effects in the country, but also that the impact is heterogeneous in the territory. Although the average effect is adverse, there are winners and losers in the process. Climate 
change is likely to increase regional disparities across Brazilian municipalities and states.

\section{References}

Abidoye, B.O. and F.O. Ayodele (2015), 'Climate change and economic growth in Africa: an econometric analysis', Journal of African Economies 24(1): 1-25.

Adams, R.M. (1989), 'Global climate change and agriculture: an economic perspective', American Journal of Agricultural Economics 71(5): 1272-1279.

Adams, R.M., C. Rosenzweig, and R.M. Pearl (1990), 'Global climate change and U.S. agriculture', Nature 345(6272): 219-224.

Assunção, J.J. (2008), 'Rural organization and land reform in Brazil: the role of nonagricultural benefits of landholding', Economic Development and Cultural Change 56(4): 851-870.

Banerjee, A. V. and A. Newman (1993), 'Occupational choice and the process of development', Journal of Political Economy 101: 274-298.

Berry, R.A. and W.R. Cline (1979), Agrarian Structure and Productivity in Developing Countries, Baltimore: Johns Hopkins University Press.

Callaway, J.M, F.J. Cronin, J.W. Currie, and J. Tawil (1982), 'An analysis of methods and models of assessing the direct and indirect economic impacts of $\mathrm{CO}_{2}$-induced environmental changes in the agricultural sector of the U.S. economy', Pacific Northwest Laboratory Working Paper 4384, Pacific North-West Laboratory, Richland, WA.

Christensen, J.H., B. Hewitson, A. Busuioc, et al. (2007), 'Regional climate projections', in S. Solomon, D. Qin, M. Manning, Z. Chen, M. Marquis, K.B. Averyt, M. Tignor, and H.L. Miller (eds), Climate Change 2007: The Physical Science Basis, Contribution of Working Group I to the Fourth Assessment Report of the Intergovernmental Panel on Climate Change, Cambridge: Cambridge University Press, Chapter 11, pp. 847-940.

Cubasch, U., D. Wuebbles, D. Chen, M.C. Facchini, D. Frame, N. Mahowald, and J.G. Winther (2013), 'Introduction', in T.F. Stocker, D. Qin, G.-K. Plattner, M. Tignor, S.K. Allen, J. Boschung, A. Nauels, Y. Xia, V. Bex, and P.M. Midgley (eds.), Climate Change 2013: The Physical Science Basis, Contribution of Working Group I to the Fifth Assessment Report of the Intergovernmental Panel on Climate Change, Cambridge: Cambridge University Press, Chapter 1, pp. 119-158.

de Janvry, A., N. Key, and E. Sadoulet (1997), 'Agricultural and rural development policy in Latin America: new directions and new challenges', Agricultural Policy and Economic Development Series-2, Rome: FAO.

Deressa, T.T. and R.M. Hassan (2009), 'Economic impact of climate change on crop production in Ethiopia: evidence from cross-section measures', Journal of African Economies 18(4): 529-554.

Deschênes, O. and M. Greenstone (2007), 'The economic impact of climate change: evidence from agricultural profits and random fluctuations in weather', The American Economic Review 97 (1): 354-385.

Di Falco, S. and M. Veronesi (2013), 'How can African agriculture adapt to climate change? A counterfactual analysis from Ethiopia', Land Economics 89(4): 761-784.

Galor, O. and J. Zeira (1993), 'Income distribution and macroeconomics', Review of Economic Studies 60(1): 35-52.

Huang, H., M. von Lampe, and F. van Tongeren (2011), 'Climate change and trade in agriculture', Food Policy 36: 9-13.

IPCC (2007a), Climate Change 2007: Synthesis Report, Contribution of Working Groups I, II and III to the Fourth Assessment Report of the Intergovernmental 
Panel on Climate Change, Core Writing Team, R.K. Pachauri and A. Reisinger (eds), Geneva: IPCC.

IPCC (2007b), 'Summary for policymakers', in S. Solomon, D. Qin, M. Manning, Z. Chen, M. Marquis, K.B. Averyt, M. Tignor, and H.L. Miller (eds.), Climate Change 2007: The Physical Science Basis, Contribution of Working Group I to the Fourth Assessment Report of the Intergovernmental Panel on Climate Change, Cambridge: Cambridge University Press, pp. 2-18.

Jeong, H. and R. Townsend (2007), 'Sources of TFP growth: occupational choice and financial deepening', Economic Theory 32(1): 179-221.

Jeong, H. and R. Townsend (2008), 'Growth and inequality: model evaluation based on an estimation-calibration strategy', Macroeconomic Dynamics 12(S2): 231-284.

Kumar, R. and H.R. Gautam (2014), 'Climate change and its impact on agricultural productivity in India', Journal of Climatological Weather Forecasting 2(1): 2-109.

Kurukulasuriya, P., R. Mendelsohn, R. Hassan, and J. Benhin (2006), 'Will African agriculture survive climate change?', The World Bank Economic Review 20(3): 367-388.

Kurukulasuriya, P. and R. Mendelsohn (2008), 'Crop switching as an adaptation strategy to climate change', African Journal of Agriculture and Resource Economics 2(1): 105-125.

Lybbert, T.J. and D.A. Sumner (2012), 'Agricultural technologies for climate change in developing countries: policy options for innovation and technology diffusion', Food Policy 37(1): 114-123.

Mendelsohn, R., A. Basist, A. Dinar, P. Kurukulasuriya, and C. Williams (2007a), 'What explains agricultural performance: climate normals or climate variance?', Climatic Change 81(1): 85-99.

Mendelsohn, R., A. Basist, P. Kurukulasuriya, and A. Dinar (2007b), 'Climate and rural income', Climatic Change 81: 101-118.

Mendelsohn, R., A. Dinar, A. Basist, and P. Kurukulasuriya (2004), 'Cross-sectional analysis of climate change impacts', World Bank Policy Research Working Paper 3350.

Mendelsohn, R., A. Dinar, and A. Sanghi (2001), 'The effect of development on the climate sensitivity of agriculture', Environment and Development Economics 6: 85-101.

Mendelsohn, R., W. Nordhaus, and D. Shaw (1994), 'The impact of global warming on agriculture: a Ricardian approach', The American Economic Review 84(4): 753-771.

New, M., D. Lister, M. Hulme, and I. Makin (2002), 'A high-resolution data set of surface climate over global land areas', Climate Research 21: 1-25.

Randall, D.A., R.A. Wood, S. Bony, et al. (2007), 'Climate models and their evaluation', in S. Solomon, D. Qin, M. Manning, Z. Chen, M. Marquis, K.B. Averyt, M.Tignor, and H.L. Miller (eds), Climate Change 2007: The Physical Science Basis, Contribution of Working Group I to the Fourth Assessment Report of the Intergovernmental Panel on Climate Change, Cambridge: Cambridge University Press, Chapter 8, pp. 589-642.

Sanghi, A. and R. Mendelsohn (2008), 'The impacts of global warming on farmers in Brazil and India', Global Environmental Change 18: 655-665.

Cohen, I.S., Ú.O. Spring, G.D. Padilla, J.C. Paredes, M.A. Inzunza Ibarra, R.L. López, and J.V. Díaz (2012), 'Forced migration, climate change, mitigation and adaptive policies in Mexico: some functional relationships', International Migration 51(4): $53-72$.

Seo, S.N. (2010), 'A microeconometric analysis of adapting portfolios to climate change: adoption of agricultural systems in Latin America', Applied Economic Perspectives and Policy 32(3): 489-514. 
Seo, S.N. (2013), 'An essay on the impact of climate change on US agriculture: weather fluctuations, climatic shifts, and adaptation strategies', Climatic Change 121: $115-124$.

Seo, S.N. (2015), 'The theory of the micro-behavioral economics of global warming', in Micro-Behavioral Economics of Global Warming: Modeling Adaptation Strategies in Agricultural and Natural Resource Enterprises, Switzerland: Springer International Publishing, Chapter 2, pp. 11-28.

Seo, S.N. and R. Mendelsohn (2008a), 'A Ricardian analysis of the impact of climate change impacts on South American farms'. Chilean Journal of Agricultural Resources 68: 69-79.

Seo, S.N. and R. Mendelsohn (2008b), 'Measuring impacts and adaptations to climate change: a structural Ricardian model of African livestock management', Agricultural Economics 38: 151-165.

Timmins, C. (2006), 'Endogenous land use and the Ricardian valuation of climate change', Environmental and Resource Economics 33: 119-142.

Wang, J., R. Mendelsohn, A. Dinar, J. Huang, S. Rozelle, and L. Zhang (2008), 'Can China continue feeding itself? The impact of climate change on agriculture', Policy Research Working Paper 4470, World Bank, Washington, DC.

Wilby, R.L., J. Troni, Y. Biot, L. Tedd, B.C. Hewitson, D.M. Smithe, and R.T. Sutton (2009), 'A review of climate risk information for adaptation and development planning', International Journal of Climatology 29: 1193-1215.

Wood, S.A. and R. Mendelsohn (2015), 'The impact of climate change on agricultural net revenue: a case study in the Fouta Djallon, West Africa', Environment and Development Economics 20(1): 20-36. 


\section{Appendix: GCMs used in the analysis}

Table A1. Description of the data

\begin{tabular}{|c|c|c|c|c|}
\hline Model ID, country, year & Atmosphere, resolution & Ocean, resolution & Temperature (annual and seasonal) & Precipitation (annual and seasonal) \\
\hline BCCR-BCM2.0, Norway, 2005 & $\mathrm{~T} 63\left(\sim 1.9^{\circ} \times 1.9^{\circ}\right) \mathrm{L} 31$ & $0.5-1.5^{\circ} \times 1.5^{\circ} \mathrm{L} 35$ & & $x$ \\
\hline CCSM3, USA, 2005 & $\mathrm{~T} 85\left(\sim 1.4^{\circ} \times 1.4^{\circ}\right) \mathrm{L} 26$ & $0.3-1^{\circ} \times 1^{\circ} \mathrm{L} 40$ & & $x$ \\
\hline CGCM3.1(T47), Canada, 2005 & $\mathrm{~T} 47\left(\sim 2.8^{\circ} \times 2.8^{\circ}\right) \mathrm{L} 31$ & $1.9^{\circ} \times 1.9^{\circ} \mathrm{L} 29$ & $x$ & $x$ \\
\hline CNRM-CM3, France, 2004 & $\mathrm{~T} 63\left(\sim 1.9^{\circ} \times 1.9^{\circ}\right) \mathrm{L} 45$ & $0.5-2^{\circ} \times 2^{\circ} \mathrm{L} 31$ & & $x$ \\
\hline CSIRO-Mk3.0, Australia, 2001 & $\mathrm{~T} 63\left(\sim 1.9^{\circ} \times 1.9^{\circ}\right) \mathrm{L} 18$ & $0.8^{\circ} \times 1.9^{\circ} \mathrm{L} 31$ & $x$ & $x$ \\
\hline ECHAM5/MPI-OM, Germany, 2005 & $\mathrm{~T} 63\left(\sim 1.9^{\circ} \times 1.9^{\circ}\right) \mathrm{L} 31$ & $1.5^{\circ} \times 1.5^{\circ} \mathrm{L} 40$ & $x$ & $x$ \\
\hline ECHO-G, Germany/Korea, 1999 & $\mathrm{~T} 30\left(\sim 3.9^{\circ} \times 3.9^{\circ}\right) \mathrm{L} 19$ & $0.5-2.8^{\circ} \times 2.8^{\circ} \mathrm{L} 20$ & & $x$ \\
\hline GFDL-CM2.0, USA, 2005 & $2.0^{\circ} \times 2.5^{\circ} \mathrm{L} 24$ & $0.3-1.0^{\circ} \times 1.0^{\circ} \mathrm{L} 20$ & $x$ & $x$ \\
\hline GFDL-CM2.1, USA, 2005 & $2.0^{\circ} \times 2.5^{\circ} \mathrm{L} 24$ & $0.3-1.0^{\circ} \times 1.0^{\circ} \mathrm{L} 20$ & & $x$ \\
\hline GISS-AOM, USA, 2004 & $3.0^{\circ} \times 4.0^{\circ} \mathrm{L} 12$ & $3.0^{\circ} \times 4.0^{\circ} \mathrm{L} 16$ & $x$ & $x$ \\
\hline GISS-EH, USA, 2004 & $4.0^{\circ} \times 5.0^{\circ} \mathrm{L} 20$ & $2.0^{\circ} \times 2.0^{\circ} \mathrm{L} 16$ & & $x$ \\
\hline GISS-ER, USA, 2004 & $4.0^{\circ} \times 5.0^{\circ} \mathrm{L} 20$ & $4.0^{\circ} \times 5.0^{\circ} \mathrm{L} 13$ & & $x$ \\
\hline INM-CM3.0, Russia, 2004 & $4^{\circ} \times 5^{\circ} \mathrm{L} 21$ & $2^{\circ} \times 2.5^{\circ} \mathrm{L} 33$ & & $x$ \\
\hline IPSL-CM4, France, 2004 & $2.5^{\circ} \times 3.75^{\circ} \mathrm{L} 19$ & $1-2^{\circ} \times 2^{\circ} \mathrm{L} 31$ & & $x$ \\
\hline MIROC3.2 (medres), Japan, 2004 & $\mathrm{~T} 42\left(\sim 2.8^{\circ} \times 2.8^{\circ}\right) \mathrm{L} 20$ & $0.5-1.4^{\circ} \times 1.4^{\circ} \mathrm{L} 44$ & $x$ & $x$ \\
\hline MIROC3.2 (hirres), Japan, 2004 & $\mathrm{~T} 106\left(\sim 1.1^{\circ} \times 1.1^{\circ}\right) \mathrm{L} 56$ & $0.2-1.4^{\circ} \times 0.3^{\circ} \mathrm{L} 47$ & $x$ & $x$ \\
\hline MRI-CGCM2.3.2, Japan, 2003 & $\mathrm{~T} 42\left(\sim 2.8^{\circ} \times 2.8^{\circ}\right) \mathrm{L} 30$ & $0.5-2.0^{\circ} \times 2.5^{\circ} \mathrm{L} 23$ & & $x$ \\
\hline PCM, USA, 1998 & $\mathrm{~T} 42\left(\sim 2.8^{\circ} \times 2.8^{\circ}\right) \mathrm{L} 26$ & $0.5-0.7^{\circ} \times 1.1^{\circ} \mathrm{L} 40$ & $x$ & $x$ \\
\hline UKMO-HadCM3, UK, 1997 & $2.5^{\circ} \times 3.8^{\circ} \mathrm{L} 19$ & $1.5^{\circ} \times 1.5^{\circ} \mathrm{L} 20$ & & $x$ \\
\hline
\end{tabular}

Emission scenario: A1B.

Spatial extent: Global.

Present time period: $1980-1999$.

Future time period: $2030-2049$.

Methodology: All of the GCM outputs as netCDF files were brought into ArcGIS 9.2 as point coverages, due to the spatially variable grain cell sizes of many of the GCM outputs. The scripting language Python 2.4.1 was used to select time ranges, calculate range means for each model and automate the subsequent process. The point coverages were converted to grids, with the resolutions specified above for each model, except that square grid cell resolutions were used. (The dimension was the minimum if the original resolution was rectangular). The grids were interpolated using kriging to fill in any missing values globally. All grids were resampled to a 2 degree resolution. The ensemble means (temperature) and medians (precipitation) were then calculated. 